\title{
INFLUENCE OF COMPUTER USE ON SCHOOLS' CURRICULUM: LIMITED INTEGRATION
}

\author{
Tjeerd Plomp, Willem J. Pelgrum and Anke H. M. Steerneman \\ University of Twente, Department of Education, Postbus 217, 7500 AE Enschede, The Netherlands
}

(Received 30 March 1989)

\begin{abstract}
In the literature many claims are formulated about what might be accomplished in actual teaching practice when computers are used in a proper and intensive way. Therefore, in this study we analyse how three leading schools in the lower general secondary education sector in The Netherlands are using computers in their curriculum. The results show that these schools have hardly passed the stage of grassroot developments. To validate and possibly generalize these results we did, as a follow up study, a telephone survey with a larger group of leading schools. The survey confirmed the outcomes of the case studies.
\end{abstract}

\section{INTRODUCTION}

Nowadays, computers are widespread in schools in Western Europe and Northern America, Becker[1], for example, reports that computers are used for instruction in more than $90 \%$ of U.S.-high schools. In The Netherlands in $1986,69.3 \%$ of the schools in lower secondary education were using computers for instruction[2], while a national plan of action will result in equipping $100 \%$ of the schools doing so by the first half of 1989 [3]. Similar developments are taking place in other countries.

Next to the "old" problems related to the introduction of computers in education, i.e. to train teachers adequately and to provide for sufficient educational software and hardware [4], these developments are resulting in a growing attention to the curricular consequence and implementation aspects of the introduction of computers in education [5].

With respect to the curricular aspects, many claims are formulated in the literature about possible consequences of using computers properly and intensively. Some of these claims are:

-educational goals and objectives may change in the direction of more emphasis on productive skills (as opposite to reproductive skills) like problem solving, information handling, inquiry skills, etc. [6-9].

- the content of the curriculum may change towards more opportunities for students to work on more real-life problems $[10,11]$;

-the teaching strategies and, as a consequence, the role of teachers may change[12];

-students will work more in small groups, or individually at the computer[13], in different locations and for different periods of time;

- the assessment of students' achievement may change[14,15].

With respect to the implementation of computer use by schools and teachers, one may suspect that an important part of the disappointments when introducing computers in schools [16] is due to paying insufficient attention to factors which play a crucial role in implementing educational changes, see, for example,[17-19]. There are hardly any reported empirical data about whether and how schools and teachers are integrating computers in their daily practice and what factors are determining successes and failures.

Surveys like those of Becker[1] and the Dutch Inspectorate [2] give rise to the expectation that in many schools some degree of integration of the computer in the curriculum of existing subjects may be expected. It is therefore worthwhile to study the changes which took place in these schools, to trace the factors which were determining these changes and to investigate what further developments might be expected. 


\section{RESEARCH QUESTION}

The central question in this study is what changes are taking place in the curricula of existing school subjects as a consequence of the integration of computers in these curricula?

First the concepts of curriculum and integration of computers will be defined.

A curriculum means almost literally "a plan for learning" [20]. We will restrict ourselves mainly to curricula on the level of the concrete teaching-learning situation. The products and documents on this level are referred to as curricula materials or, when software is included, courseware. We can distinguish curriculum components or dimensions[21,22], such as objectives, content, instructional strategies (including methods and media), grouping patterns, materials, student evaluation, time, and space. When we are talking about computers in the curriculum, we are in principle referring to all eight components of the curriculum. Integration of computers in school curricula may affect any of these components.

\section{Integration of computers in education}

In agreement with Mudd and Wilson[23] a quantitative and a qualitative dimension can be distinguished in describing the degree of integration of computers in a school's curriculum [24]. The quantitative aspect refers to descriptive variables indicating the frequency and intensity of computer used. For example, at the school level we may think of the number of subjects, grades, classes per grade, teachers per subject, and numbers of students (all or a special group) who use school computers. Quantitative integration within subjects refers to variables such as the frequency of use per student per time period, the time spent on the computer each time it is used, and the number of software packages being used. Qualitative aspects are those referring to types of objectives; to teachers' activities or the lesson phases in which the computer can be used (such as presentation of new subject matter, practising, testing, feedback); to students' activities; and to the "level" or complexity of computer applications, which may vary from a relatively low level of drill and practice or word processing to more sophisticated applications such as simulations or computer coaches. The integration of the computer in the curriculum in both quantitative and qualitative aspects can be discussed for each of the abovementioned curriculum manifestations.

Without trying to construct a measure for the integration of the computer in the curriculum, we shall, after investigating the use of computers in a school, give an indication of the degree of integration of computers in the curricula of Dutch secondary schools.

\section{RESEARCH DESIGN}

In this study we will restrict ourselves to Dutch junior secondary (non-vocational) schools. A further restriction is that only the use of computers in existing subjects was studied (which implies, for example, the exclusion of computer use in new courses like computer literacy or informatics).

From the survey of the Inspectorate[2] it was known that, although many schools are having computers, the use of computers in regular courses is very limited. To enlarge the chance to observe changes in the curriculum in schools as consequences of computer use, it was decided to focus the study on schools which could be considered as "leading schools" with respect to computer use.

To be able to analyse computer use in schools in depth, and given the exploratory character of the study a case study methodology is appropriate. In this study we applied an embedded multiple case design [25]. From the survey and interviews of the Dutch Inspectorate[2], the Inspectorate selected three schools in the sector of lower secondary education, which could be considered as leading schools. The selected schools were willing to cooperate in the case study.

To be able to generalize the results of the case studies, and to correct for possible bias in the selection of the leading schools by the Inspectorate, it was decided to do a follow up of the case studies by means of a telephone survey among a sample of leading schools.

For the case studies in each of the three schools the following procedure was used. The principal and the computer coordinator of the school were interviewed in order to collect context information about, for example, the history, policy and the degree of computer use at school level, the available facilities, and information about the factors which (according to, for example, Fullan [17]) influence the implementation of an innovation. The computer coordinator was asked to indicate the three 
subjects in which the computer was being used the most, and then for each subject, a teacher who used the computer, as well as a teacher who did not use the computer, was interviewed. The "using" teachers gave information about how they were using computers, what changes had taken place in their curriculum as a consequence of this use, and what factors influenced their use. The "non-using" teachers gave their arguments for (still) being a non-user. Besides, for each selected subject, some lessons in which the computer was used were observed, as well as some other lessons. Furthermore, documents on the school's policy about computer use and curricular materials (including educational software) were analysed.

We sometimes had to deviate from this procedure, due to the circumstances in the schools; e.g. in one of the schools the computer was only used in two subjects.

As instruments for the case studies several questionnaires were developed to serve as a checklist during the interviews. Furthermore, checklists were constructed to analyse software and other materials which were used in the classroom, as well as for the observation of the lessons, so that changes in the level of curriculum-materials and in the operational level could be established.

To take care of the validity of the case studies, several sources and methods were used to collect the same information and the draft reports of the case-studies were checked for completeness and correctness by the interviewed persons. The procedure for data collection, the checklists for the interviews, and storage of the collected data in a database (so that they were available for systematic analysis) contribute to the reliability of the study.

The telephone survey followed the case studies to validate and to investigate the generalizability the results of the case studies. From other studies[2,24] we knew that in the sector of junior general secondary education, 28 schools could be considered as leading schools. As 7 of these schools were already involved in other research projects of our institute, 21 schools were eligible for this survey; 16 were willing to cooperate.

A school questionnaire and a teacher questionnaire were used as instruments; both instruments to be answered in maximal $15 \mathrm{~min}$. The school questionnaire, answered by the school's computer coordinator, asked for the degree of integration of the computer in the curriculum and for implementation influencing factors, both at school level. The teacher questionnaire was answered by the teacher who was according to the computer coordinator, the most intensive computer using teacher at the junior level in the school. The teacher questionnaire addressed the same topics, but at the micro-level, i.e. the level of the operational curriculum of that particular teacher.

Data collection took place in the course year 1986/1987 (case studies) and 1987/1988 (telephone survey).

\section{RESULTS}

In this section the national context and some characteristics of the case study schools will first be presented, and this may serve as an interpretation context for the remaining results. Next, computer facilities and use on school level, the existing conditions for implementation and computer use on subject matter level will be discussed. Finally, changes in the curriculum will be analysed on the curricular variables, as mentioned in Section 2.

\subsection{National and school context}

A National Informatics Stimulation Plan, a 5-year program, was executed in The Netherlands from 1984 till the end of 1988 . The educational part directed at general secondary education was a cooperation of the government, the proper authorities of the schools, and some computer manufacturers. The goals were to provide each lower secondary school with $9 \mathrm{MS} / \mathrm{DOS}$ microcomputers in a Local Area Network (LAN) and two additional machines, to train three teachers per school in the use of computers in education (familiarization course) and to provide a national infrastructure for software development. The provision of all schools with the same type of hardware will self-evidently lead in the near future to a certain standardization of hardware.

The three schools in the case study are in the sector of general secondary education; two of them, viz. $A$ and $B$, were already provided with hardware and had three teachers trained in the context of the national plan at the time of data collection. It should be noted that all schools (private as 
well as public ones) in The Netherlands are paid for by the government; schools may also raise funds by themselves, e.g. via an extra contribution by the parents.

Some characteristics of the case study schools are:

School A: private, part of an organization with 49 schools in several cities; contains pre-university and higher general secondary education; grade range 1-6, age range 12-18; 67 teachers; 1180 students.

School B: public; contains pre-university education, higher and middle general secondary education; grade range $1-6$, age range 12-18; 100 teachers; 1700 students.

School C: private, part of an organization with three schools in one city; contains middle general secondary education only; grade range $1-4$, age range $12-16 ; 21$ teachers; 274 students.

Although two of the schools have a grade range of 1-6, the case studies were restricted to the lower secondary education grades, i.e. grades $1-3$. It is important to stress that school A is part of a large private association which governs many schools.

Of the survey schools, 5 are of the same type as school A, 7 of the type of school B, and 4 of the type of school C. The sizes of the three case study schools are within the range of the survey schools.

\subsection{Computer facilities and uses in the schools}

Before discussing the use of computers in the three case study schools, we first present an overview of the available facilities:

School A: 13 Commodore-64 and 13 IBM-MS/DOS computers. 8 Commodores are placed in a LAN as well as 8 IBMs, both LANs are placed in the computer laboratory for students. Most of the other computers are placed in the computer laboratory for teachers.

School B: New Brain computers and 28 Philips-MS/DOS computers. Of the Philips computers, 22 are placed in a computer laboratory and 9 of those in a LAN.

School C: 9 TANDY computers, of which 8 in a LAN in the computer laboratory.

As a consequence of the grassroots developments, which started before the execution of the national informatics stimulation plan, different computer types are present in the schools. Schools $A$ and $B$ acquired their MS/DOS machines not only as part of the national scheme, but also as part of other projects in which they participated. The organization of the computers in school B allows for using computers with a full class ( 1 or 2 students per machine) which is more optimal as compared to schools $\mathrm{A}$ and $\mathrm{C}$ ( 2 or 3 students per machine). It should be noted that school A does possess the hardware to create a more optimal situation in terms of computer: student ratio. Schools A and C are "early" users, they started using computers in 1974 and 1975 respectively, while school B got involved in a special project in 1983.

Table 1 summarizes the available facilities in the schools (including personnel resources), available software and in which subjects, grades and by how many teachers these are used.

From this table, we see that school $\mathbf{A}$ is active with computers in many more subjects than the other two schools; also a relatively higher number of teachers in school $\mathrm{A}$ is involved. It should further be noted that there are great differences between the schools in the choice of subjects and grades in which computers are being used; this confirms that there is clearly no centralizing tendency in the Dutch national policy which is directing schools.

Almost all the software used is developed within the school, which points to an overall lack of software in the public domain.

All schools do have a computer coordinator, but only in school A this person has less than a normal teaching load to be able to coordinate computer activities. The number of periods for other teachers to spend on computer-related activities is also the largest in this school.

The teachers in school $\mathrm{C}$ received only an internal programming course before starting to use computers. The other schools organized internal introductory courses on how to use computers, while as part of the national scheme, three teachers per school were allowed to take part in an 
Table 1. Personnel resources and computer use in case study schools (from [28])

\begin{tabular}{|c|c|c|c|c|c|c|}
\hline \multirow[b]{2}{*}{ Personnel responses } & \multirow[b]{2}{*}{ Subjects } & \multicolumn{5}{|c|}{ Aspects of computer use* } \\
\hline & & 1 & 2 & 3 & 4 & 5 \\
\hline $\begin{array}{l}\text { School A } \\
1 \text { computer coordinator with } 13 \text { special periods } \\
14 \text { special periods of other teachers } \\
52 \% \text { teachers trained by internal introductory course } \\
4 \% \text { teachers trained by national scheme }\end{array}$ & $\begin{array}{l}\text { Engish } \\
\text { French } \\
\text { Geography } \\
\text { Mathematics } \\
\text { Mother tongue } \\
\text { Physics }\end{array}$ & $\begin{array}{c}5 \\
75 \\
2 \\
20-30 \\
15 \\
20-30 \\
95 \%\end{array}$ & $\begin{array}{l}5 / 13 \\
5 / 5 \\
3 / 3 \\
4 / 4 \\
4 / 6 \\
3 / 3 \\
\text { oftwar }\end{array}$ & $\begin{array}{l}2,3 \\
1-3 \\
1 \\
1,2 \\
1-3 \\
2,3 \\
\text { eifma }\end{array}$ & $\begin{array}{c}13 / 13 \\
19 / 19 \\
7 / 7 \\
13 / 13 \\
5 / 13 \\
13 / 13 \\
5 \% \pi C\end{array}$ & $\begin{array}{l}\text { All } \\
\text { la. } \\
\text { All } \\
\text { All. la. } \\
\text { la. } \\
\text { All } \\
\text { ired }\end{array}$ \\
\hline $\begin{array}{l}\text { School } \\
1 \text { computer cootclinator without special periods } \\
4 \text { special periods for other teachers } \\
30 \% \text { teachers trained by internal introductory course } \\
3 \% \text { teachers trained by national scheme }\end{array}$ & $\begin{array}{l}\text { Mother tongue } \\
\text { Physics }\end{array}$ & 12 & $\begin{array}{l}2 / 12 \\
3 / 5\end{array}$ & $\begin{array}{l}3 \\
2\end{array}$ & $\begin{array}{l}2 / 16 \\
16 / 16\end{array}$ & $\begin{array}{l}\text { All } \\
\text { All }\end{array}$ \\
\hline $\begin{array}{l}\text { School } C \\
1 \text { computer coordinator with I special period } \\
1 \text { special period for other teachers } \\
80 \% \text { teachers followed internal programming course }\end{array}$ & $\begin{array}{l}\text { French } \\
\text { Mathematics } \\
\text { Music }\end{array}$ & $\begin{array}{c}4 \\
4 \\
89 \%\end{array}$ & $\begin{array}{l}1 / 1 \\
3 / 4 \\
1 / 1 \\
\text { ftware }\end{array}$ & $\begin{array}{r}1,2 \\
1,2 \\
1-3 \\
\text { elfma }\end{array}$ & $\begin{array}{r}6 / 6 \\
\$ / 6 \\
9 / 9 \\
1 \%\end{array}$ & $\begin{array}{r}\text { All } \\
\text { All } \\
\text { All } \\
\text { uired }\end{array}$ \\
\hline
\end{tabular}

*1, No. of programs; 2 No. of using teachers out of total using teachers (e.g. 5/13:5 out of 13 teachers); 3 grades in which computers are used; 4, No. of classes in which computers are used out of total number of elasses; 5 , kype of students who are using computers all students or lower ability (l.a.).

external course. No teachers of school $\mathrm{C}$ participated in other external courses, although they were available.

From Table 1, it can be concluded that in school A computer use in french, mathematics and mother tongue is especially for lower ability students; in this school, it was decided to restrict the use of computers mainly to teaching outside the normal classes for remedial purposes.

In summary, we may conclude that only in school A a certain degree of integration of computers in the school can be observed; in the other schools, the developments-even when they have lasted for several years as in school $\mathrm{C}$-are very modest. In these schools, one cannot speak of any real integration of computers in the school curriculum.

Case study schools compared with survey schools. When we compare the case study schools with the survey schools on the number of computers they have (Fig. 1) we may conclude that the case study schools are well spread over the distribution of number of computers per school. The relative favourable position of school $\mathrm{A}$ is clear from this figure.

From Table 1 we know in which subjects in the case study schools the computer is used. Looking at the number of subjects the computer is used in, Fig. 2 illustrates again that the case study schools are well spread over the distribution of all schools. From the telephone survey we know that in the survey schools computers are mostly used for only one grade per subject. Based on Fig. 3 we can draw a similar conclusion about the number of teachers in each school who are using the

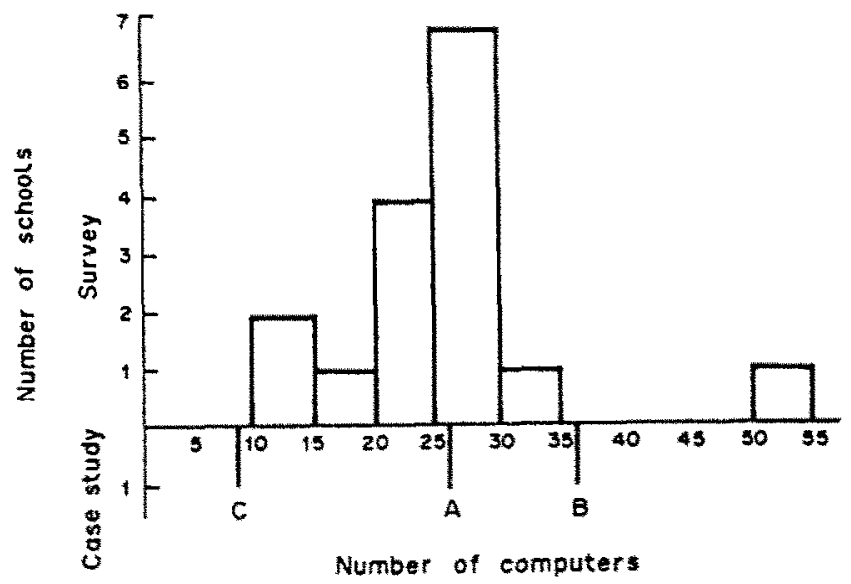

Fig. 1. Distribution of the number of schools over the number of eomputers. 


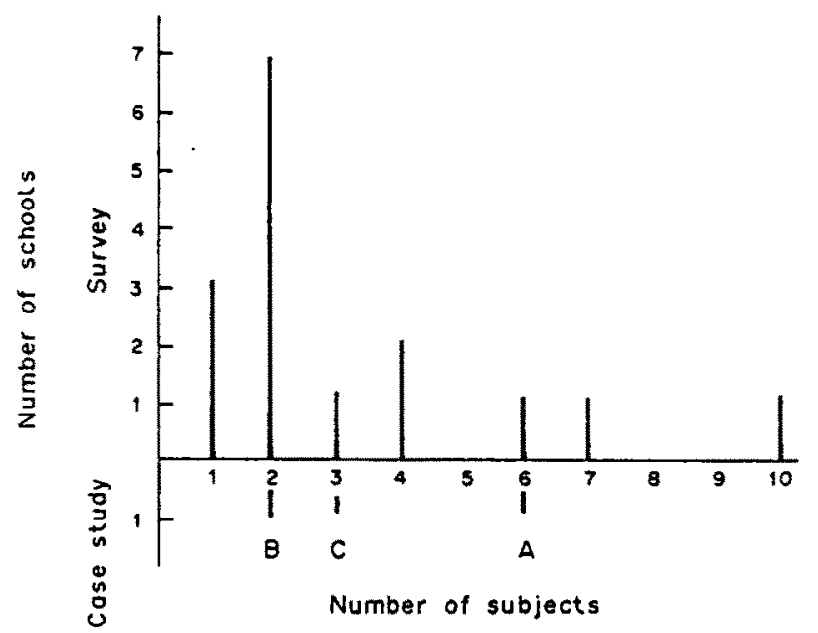

Fig. 2. Distribution of the number of schools over the number of subjects in which computers are used $(N=19)$.

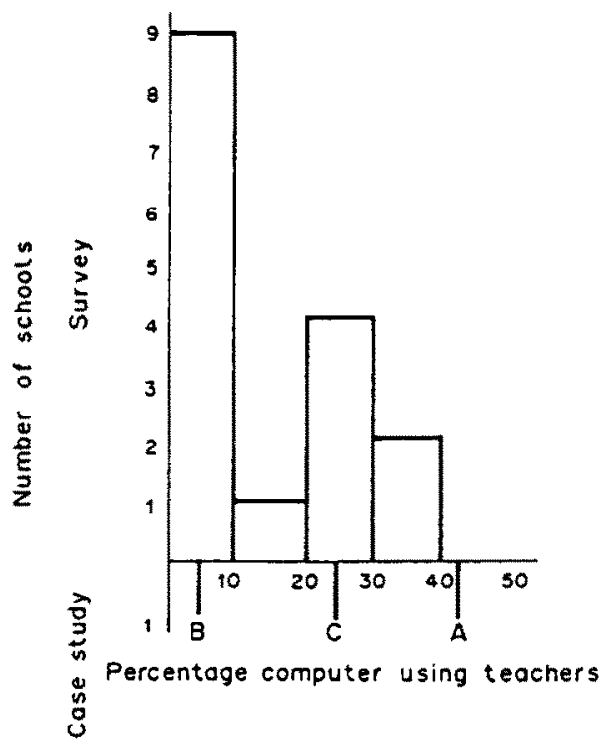

Fig. 3. Distribution of the number of schools over computer-using teachers.

computer: schools $\mathrm{B}$ and $\mathrm{C}$ do not deviate much from the other schools, but school $\mathrm{A}$ has the highest number of computer using teachers of all schools under investigation. Fourteen of the 16 survey schools do have a computer coordinator.

Comparing the case study schools with the survey schools, we may conclude that both type of schools are not differing much in the integration of computers in their curricula. This means a validation of our earlier conclusion that, although in the leading schools many activities with computers are taking place, one cannot speak of a real integration of computers in the schools' curriculum.

\subsection{Factors influencing implementation}

The question may be asked which factors are determining this rather disappointing picture of integration of computers in the curricula of schools who are considered by the inspectorate as leading schools. Summarizing the literature on the implementation of innovations, Fullan [18] concludes: "It is known that change in practice occurs when certain elements occur in combination: attention to the development of clear and validated materials; active administrative support and leadership at the district and especially the school level; focused, ongoing inservice or staff development activities; the development of collegiality and other interaction-based conditions at the school level; and the selective use of external resources (both people and materials)". Data collected in the three case study schools on many of these elements are summarized in Table 2.

Some conclusions can be drawn from these data. First, none of the schools has a clear educational vision of what they would like to achieve with the new technologies; the statements are vague, there is no written policy presenting "leading ideas" which may structure activities on school level. Given Fullan's elements, we can say that

-there is a need for materials, also for time for teachers;

-there is administrative support on school level, but the administration is merely stimulating that something should be undertaken and not "what, why and how" (schools B and C reported also organizational problems on how to use the computers); it is illustrative that in one of the schools the administration reported no problems, while the computer coordinator mentioned the lack of policy at school-level as one;

-we concluded earlier that the national scheme is imposing some conditions at school level, but it is not including directions for the developments at school level; this was also manifest from the interviews;

-there is not a continuous ongoing process of staff development in the schools; 
Table 2. Some implementation factors, partly reported by (vice-) principles and computer coordinator (from [28])

\begin{tabular}{|c|c|c|c|}
\hline $\begin{array}{l}\text { Schools } \\
\text { Factors }\end{array}$ & $A^{*}$ & B & C \\
\hline Reason to start & $\begin{array}{l}\text { Possibilities to implement new } \\
\text { teaching strategies }\end{array}$ & $\begin{array}{l}\text { Use of computers by schools } \\
\text { became usual (rivairy) } \\
\text { Possibilities to implement new } \\
\text { teaching strategies }\end{array}$ & $\begin{array}{l}\text { Possibilities to use the computer } \\
\text { in school } \\
\text { Chance for school to become a } \\
\text { leading school }\end{array}$ \\
\hline Policy & $\begin{array}{l}\text { No written or informal long-term } \\
\text { policy }\end{array}$ & $\begin{array}{l}\text { No written or informal long-term } \\
\text { policy }\end{array}$ & $\begin{array}{l}\text { No written or informal } \\
\text { long-term policy }\end{array}$ \\
\hline Facilities & $\begin{array}{l}\text { Lack of hardware, memory } \\
\text { capacity, software and time }\end{array}$ & $\begin{array}{l}\text { Lack of software, time and } \\
\text { finances }\end{array}$ & $\begin{array}{l}\text { Lack of hardware, software and } \\
\text { time, slow network }\end{array}$ \\
\hline Organization & & $\begin{array}{l}\text { Problems with scheduling the use } \\
\text { of computer laboratory }\end{array}$ & $\begin{array}{l}\text { Problems with scheduling } \\
\text { teachers tor computer } \\
\text { education } \\
\text { Problems with location of } \\
\text { computers }\end{array}$ \\
\hline External training & 3 Teachers attended & 3 Teachers attended & \\
\hline Internal training & $\begin{array}{l}\text { No follow-up on introductory } \\
\text { course }\end{array}$ & $\begin{array}{l}\text { No follow-up on introductory } \\
\text { course }\end{array}$ & No follow-up on BASIC-course \\
\hline Internal support & $\begin{array}{l}\text { Teachers and coordinator reports } \\
\text { school administration fulfills } \\
\text { necessary conditions only } \\
\text { More teachers working with } \\
\text { computers }\end{array}$ & $\begin{array}{l}\text { Teachers and coordinator report } \\
\text { that administration is } \\
\text { stimulative } \\
\text { More teachers working with } \\
\text { computers }\end{array}$ & $\begin{array}{l}\text { Teachers and coordinator report } \\
\text { that administration is } \\
\text { stimulative } \\
\text { More teachers working with } \\
\text { computers }\end{array}$ \\
\hline External support & $\begin{array}{l}\text { Government supplies hardware } \\
\text { and training } \\
\text { Board of school supplies } \\
\text { hardware, software, time, } \\
\text { information and expertise }\end{array}$ & $\begin{array}{l}\text { Government supplied hardware } \\
\text { and training } \\
\text { Board of school supplied } \\
\text { hardware } \\
\text { COl† supplies hardware and } \\
\text { expertise } \\
\text { Software from SLO+ }\end{array}$ & \\
\hline
\end{tabular}

-The administration of school A reported no problems, source of problems: the computer coordinator.

+COI, Center for Education and Information Technology.

\$SLO, National Institute for Curriculum Development.

-there is limited use of external resources, e.g. almost all software of selfmade (Table 1) and training is mainly internal.

Survey schools were also asked which factors were inhibiting the computer use in their schools. Table 3 summarizes the results; eight possible factors were presented to the respondents, under "remaining" spontaneously mentioned factors are summarized.

In the survey schools the amount and quality of software are mentioned as the main inhibiting factors. Further, lack of hardware and inservice training facilities appear to be problems. These problems are also mentioned in the case study schools. It is remarkable that in the survey schools the resistance of colleagues against computers, and the small number of computer using teachers are mentioned as constraining factors. These factors are not mentioned in the case study schools.

Although our design does not allow for inferring causal links between variables, it is clear that most of the conditions mentioned by Fullan are not fulfilled in the leading schools. The case study and the survey schools do not differ much in this respect. As this conclusion at school level does not exclude that computer use is integrated in some subject matter domains, we decided to analyse

Table 3. Factors constraining computer use: survey schools $(N=16)$

\begin{tabular}{lc}
\hline Factors & No. schools \\
\hline Lack of hardware/peripherals & 6 \\
Lack of software & 8 \\
Poor quality of software & 11 \\
Too little support of school administration & 1 \\
Too little external support & 2 \\
Too few computer using teachers & 4 \\
Too little deliberation without schools & 4 \\
Lack of inservice training facilities & 6 \\
Remaining & 3 \\
Too little time & 3 \\
Too little money & 2 \\
Problems with supervision and support in computer lab & 6 \\
Resistance of colleagues against computers & 2 \\
No computer available at home & \\
\hline
\end{tabular}


Table 4. Degree of integration of computer use at subject level (from [28])

\begin{tabular}{|c|c|c|c|c|c|c|c|c|c|}
\hline \multirow[b]{2}{*}{ Subject } & \multicolumn{4}{|c|}{ Lesson phase" } & \multicolumn{3}{|c|}{ Type of use } & \multirow[b]{2}{*}{ Frequencyt } & \multirow[b]{2}{*}{ Length: } \\
\hline & Presentation & Practice & Testing & r.t.\$ & d \& p & Simulation & Tool & & \\
\hline $\begin{array}{l}\text { School A } \\
\text { French } \\
\text { Mathernatics } \\
\text { Mother tongue }\end{array}$ & & & $x$ & $\begin{array}{l}x \\
x \\
x\end{array}$ & $\begin{array}{l}x \\
\times \\
x\end{array}$ & & $x$ & $\begin{array}{c}5 \\
3 \\
46\end{array}$ & $\begin{array}{l}50 \\
45 \\
50\end{array}$ \\
\hline $\begin{array}{l}\text { School B } \\
\text { Mother tongue } \\
\text { Physics }\end{array}$ & $x$ & $\begin{array}{l}x \\
x\end{array}$ & & & & $x$ & $x$ & $\begin{array}{r}12 \\
1\end{array}$ & $\begin{array}{l}50 \\
50\end{array}$ \\
\hline $\begin{array}{l}\text { School C } \\
\text { French } \\
\text { Mathematics 1st grade } \\
\text { Mathematics 2nd grade } \\
\text { Music }\end{array}$ & $x$ & $\begin{array}{l}x \\
x \\
x \\
x\end{array}$ & & & $\begin{array}{l}x \\
\times \\
x\end{array}$ & & $x$ & $\begin{array}{l}3 \\
4-5 \\
2-3 \\
13\end{array}$ & $\begin{array}{l}25 \\
25 \\
25 \\
-\end{array}$ \\
\hline
\end{tabular}

*Lesson phase in which computers are used.

+Frequency, number of times the computers is used per year; in the subjects where the computer is used for reteaching, this number stands for the average time the computer is used per student, per year.

†Length: average length of time spent at the computer by students.

\$r.t. remedial teaching.

Id \& p, Drill and practice.

developments in three subjects per case study school and in one subject per survey school, the results of which will be discussed in the next section.

\subsection{Computer integration on micro-level}

For each case study school, three subjects were selected in which the computer is used relatively intensively. Table 4 contains some data about computer use in these subjects.

In school $A$ a policy decision was made to use the computer predominantly for remedial purposes outside the regular lessons in a computer lab. Therefore, the use of computers was restricted to the group of low achieving students who were offered additional practice by using drill and practice software. The average frequency of use per student is about five times per year (calculated over a whole class), but there were students who were working 15 times per year with the computer, as well as students who were not working at the computer at all. In mathematics the computer is used for another purpose: 15 times a year students took a diagnostic test. The percentage of subject matter for which (remedial) courseware was available differs enormously: $99 \%$ of the French curriculum in grades 1,2 and 3, while for mother tongue this was $25 \%$ (grade 1) and $10 \%$ (grade 3), and for mathematics $40 \%$ (grade 1 and 2 ).

School $B$ had, at the time of data collection, only one piece of courseware for physics, which was used only one lesson period per year in grade 2 . Two teachers used the computer for word processing in their grade 2 classes as part of an experiment to integrate computer literacy with mother tongue. During 12 lesson periods students were familiarized in the use of the word processor and also spelling practices and texts summaries (in a drill and practice mode).

The pattern of use of the computer in school $C$ was that the first half of the lesson teaching took place in the normal classroom, while the class moved for the second part to the computer classroom to practice with the computer. There were only five pieces of courseware for french, and one for mathematics. In the music lessons the computer was used as a tool for writing and playing music; for this application the private computer of the teacher was used, as the school computers are not appropriate for this.

In summary, we may conclude that computers are not frequently used and that the use is often of the drill and practice type. Furthermore, with respect to the use of computers in school A in french, mathematics and mother tongue, it should be noted that the use is not during class periods, but only outside the class for remedial activities with low achieving students. Although a lot of activity is going on in the case study schools, no other conclusion can be drawn than that we cannot as yet speak of a real integration of the computer in existing courses.

Looking for possible explanations for this lack of integration, 9 teachers ( 1 teacher for each selected subject in each school) were asked which problems they encountered in using computers, by checking from a list of twelve possible problems those which are most important for them. Teachers who actively use computers, most frequently mention as their problems a lack of software, 
curricular materials, hardware, availability of time and organizational constraints. It is interesting that all these problems are related to factors conditional for the implementation of computers in education. Plomp and Carleer [26] found similar results in a study of problems in the implementation of information literacy, the Dutch variant of computer literacy.

When teachers were asked to explain why they used computers in their teaching only one teacher mentioned a perceived need. This teacher used the computer in physics in school B to solve the classroom management problem registering the progress of students when they work in groups. The other teachers gave more global reasons for using the computer like: to improve students achievement, to use new teaching methods, to motivate students or to meet needs of the society.

Case study schools as compared with survey schools. The case study schools are compared with the survey schools on the integration of computers in existing subjects, by comparing the 9 teachers in the case study schools with 16 teachers of the survey schools (one per school) on variables like frequency and length of computer use, percentage of subject matter covered, instructional functions, and purpose of use. The 16 survey teachers, who are in their schools the most intensive computer using teachers at the junior level, are covering a broad range of subject matter domains: geography, biology, foreign languages $(n=5)$, mother tongue $(n=3)$, chemistry, mathematics $(n=4)$ and one teacher with a double certification in mathematics and mother tongue. The results reported by Steerneman [24] will be summarized.

Frequency. 11 of the 16 survey teachers are using the computer during their lessons, 5 use computers exclusively for remedial purposes, and 2 use the computer both during their lessons and for remedial purposes. One teacher could not answer the question. Most frequencies of computer use in the case study and survey schools are in the same intervals, namely a yearly average as given in Table 3. There are two exceptions among the survey teachers: one teacher is using the computer in almost every lesson, while another one uses the computer more than 20 times per year for testing purposes.

Average length. Most survey teachers use computers during a whole class period of $50 \mathrm{~min}$, like in schools A and B; while 5 (out of the 16) survey teachers have an average length of use similar to case study school C (range $5-40 \mathrm{~min}$ ).

Percentage subject matter covered. It apeared that teachers had difficulties answering this question. Two (out of 9) case study teachers, and 5 (out of 16) survey teachers felt that they could not reply to this question. The remaining teachers do not show much difference: in most cases only $<10 \%$ is covered, in a few cases a percentage between 20 and 40 , while only one case study teacher and two survey teachers report that $>90 \%$ of the subject matter is addressed in the courseware they are using.

Type of courseware. Table 5 summarizes the frequencies.

The data suggest that in the case study in schools the computers were used most frequent as the tools in teaching and learning. However, in two of these cases it concerns teachers in mother tongue in school B who are using a word processing program predominantly for drill and practice purposes. As a consequence, in case study schools drill and practice is the dominant type of computer use. In survey schools drill and practice and tutorial are the most important uses. One remark ought to be made: we classified a program as tutorial even when there is very little explanation in it. We may conclude that in both type of schools only less advanced types of courseware are used.

Only 7 teachers in the survey schools, and 1 of the 9 teachers in the case study schools are using two types of programs, the remaining teachers only one type. This indicates a limited integration of the computer in their curricula.

Table 5. Frequency of use of different types of courseware

\begin{tabular}{lcc}
\hline & \multicolumn{2}{c}{ Number of teachers* in } \\
\cline { 2 - 3 } Types of courseware & $\begin{array}{c}\text { Case study schools } \\
(n=9)\end{array}$ & $\begin{array}{c}\text { Survey schools } \\
(n-16)\end{array}$ \\
\hline Tool & 4 & 3 \\
Drill and practice & 3 & 9 \\
Tutorial & 2 & 9 \\
Simulation & 1 & 2 \\
\hline
\end{tabular}

* Some teachers use more than one ype of courseware. 
Table 6. Instructional functions of computers

\begin{tabular}{lcc}
\hline & \multicolumn{2}{c}{ Number of teachers in } \\
\cline { 2 - 3 } Instructional & $\begin{array}{c}\text { Case study schools } \\
(n=9)\end{array}$ & $\begin{array}{c}\text { Survey schools } \\
(n=16)\end{array}$ \\
functions & 2 & 1 \\
\hline Presentation & 6 & 10 \\
Practising & 4 & 7 \\
Remedial teaching & 1 & 2 \\
Testing & & \\
\hline
\end{tabular}

Instructional functions. Teachers can use computers for different instructional functions (see Table 6).

Case study and survey schools do not differ much in this respect. The most important instructional functions for which computers are used are practising (doing exercises) and remedial teaching. Computers are hardly used for presentation of new subject matter. This may partly be caused by a lack of adequate courseware, but also by a lack of hardware. As long as teachers have to go to special computer labs or classrooms, computer usage will be very time consuming.

Purpose of comptuer use. The main purpose for using computers is to provide for extra practicing (mentioned by 7 of the 9 case study teachers, and by 9 of the 16 survey teachers).

In summary, the degree of integration of computers in existing subjects is very limited. Computer use has a low frequency, and is applied for small percentage of the subject matter. Most teachers in both types of schools are using one type of computer application, and mostly for just one instructional function.

We may conclude that there are no indications that the results from the case study schools cannot be generalized to the population of leading schools in The Netherlands.

\subsection{Changes in the curriculum}

From the results presented in the preceding sections, we conclude that computers are not yet integrated in the curriculum of leading schools, or in specific subjects in these schools. Therefore, we may not expect to find much change in the curricula. As we studied this type of changes only in the case study schools, we can only indicate very tentatively which changes occurred as a result of the limited degree of integration and experience of teachers.

In Section 1 we presented some claims about possible changes in the curriculum as a consequence of computer use as reported in the literature. One claim was that objectives would change in the direction of more attention for productive skills and that in the content of the teaching more attention would be paid to real-life problems. The contrary appeared from our analysis of the software used: less attention is being paid to productive skills and to real-life problems.

The same holds for instructional strategies: there is a claim for more inquiry oriented learning when computers are used, but the software used in the case study schools induced a more expository instructional stragtegy.

Teachers were asked about changes in the operational curriculum, that is in their instructional practices, as a consequence of computer uses. The results are summarized in Table 7. Teachers reported that students were evaluated in the same way as before computers were used, so the aspect of student evaluation in Table 7 refers to the degree of direct feedback the students receive.

We can conclude from Table 7 that teachers reported hardly any changes, except for changes which are directly related to the use of this medium, such as changes in the grouping patterns, in the degree of feedback and in the rooms which are used. First indications for possible changes in the future are reported by several teachers. In school $\mathrm{A}$, in french more attention is paid to speech practice, as the computer can take over the practising with grammar. In school B, for both subjects a change in content is reported. For the subject of mother tongue word processing is added to the curriculum, replacing some drill exercises, and for physics, the computer adds the possibility of testing connections. In school $C$, the changes reported for french and mathematics are due to spending more time on the topics which are taught with the computer.

In school B relatively more changes are reported than in school A and $\mathrm{C}$. This is probably due to the more "sophisticated" uses of the computer, such as word processing and simulation.

We may conclude that presently teachers used the less sophisticated possibilities of the computer 
Table 7. Changes as reported by teachers (from [28])

\begin{tabular}{|c|c|c|c|c|c|c|c|c|}
\hline \multirow{2}{*}{$\begin{array}{l}\text { Schooi } \\
\text { Subject }\end{array}$} & \multicolumn{3}{|c|}{$A$} & \multicolumn{2}{|c|}{ B } & \multicolumn{3}{|c|}{$\mathrm{C}$} \\
\hline & French & Math* & $\mathrm{Mi}^{+}$ & Mt & Physics & French & Math & Music \\
\hline \multicolumn{9}{|l|}{ Parts of curriculum } \\
\hline $\begin{array}{l}\text { Change in goals } \\
\text { Productive skills }\end{array}$ & $\begin{array}{l}\text { No: } \\
\text { Less\& }\end{array}$ & $\begin{array}{l}\text { No } \\
\text { Less }\end{array}$ & $\begin{array}{l}\text { No } \\
\text { Less }\end{array}$ & $\begin{array}{l}\text { Yes } \\
\text { Less }\end{array}$ & $\begin{array}{l}\text { Yes } \\
\text { Equal }\end{array}$ & $\begin{array}{l}\text { No } \\
\text { Less }\end{array}$ & $\begin{array}{l}\text { No } \\
\text { Less }\end{array}$ & No \\
\hline Change in content & No & No & No & Yes & Yes & No & No & - \\
\hline Real life content & Less & Less & Less & Less & Less & Less & Less & - \\
\hline $\begin{array}{l}\text { Discovery oriented strategy } \\
\text { Working individual or in }\end{array}$ & $\begin{array}{l}\text { Less } \\
\text { More }\end{array}$ & $\begin{array}{l}\text { Equal } \\
\text { More }\end{array}$ & $\stackrel{?}{\text { More }}$ & $\begin{array}{l}\text { Less/equal } \\
\text { More }\end{array}$ & $\begin{array}{l}\text { Less } \\
\text { More }\end{array}$ & $\begin{array}{l}\text { Equal } \\
\text { More }\end{array}$ & $\begin{array}{l}\text { Less } \\
\text { More }\end{array}$ & $\begin{array}{l}\text { Equa } \\
\text { Equa }\end{array}$ \\
\hline $\begin{array}{l}\text { groups } \\
\text { Student evaluation }\end{array}$ & More & More & Equal & Equal & More & More & \multicolumn{2}{|c|}{$\begin{array}{l}\text { More ist grade } \\
\text { equal 2nd grade }\end{array}$} \\
\hline $\begin{array}{l}\text { More than } 1 \text { room used } \\
\text { during class }\end{array}$ & NA & NA & NA & No & No & Yes & Yes & No \\
\hline $\begin{array}{l}\text { Change in time spent on } \\
\text { certain topics during class }\end{array}$ & Yes & No & No & No/yes & No & Yes & Yes & No \\
\hline
\end{tabular}

Math, mathematics.

$+\mathrm{Mt}$, Mother tongue.

¥Yes or no, the change did or did not occur as a consequence of computer use.

$\S$ More/equal/less, more/equal less in computer lessons as opposed to normal lessons.

I-, Hard to specify.

which is probably (partly) due to the fact that most software is teacher made. This software does not take advantage of the full possibilities of the computer as an educational medium. This means that the degree of integration on which most claims about possible effects are based, is still not realized.

\section{DISCUSSION}

From this study it appears that the leading schools have not integrated the use of computers, neither at school nor at subject level. Although the survey results [1,2] suggest a lot of activities with respect to computers in education, we see that leading schools have hardly passed the stage of grassroot developments. Given this situation, it is not surprising that we did not find much change in existing subjects as a result of the use of computers.

Due to these grassroot developments, there is a variety in what schools are doing with computers. It is not clear yet whether the national scheme in The Netherlands will result in more convergence of these activities at school level.

Another effect of grassroot developments is what might be called the disadvantage of early starters. We observed, for instance, at school $\mathrm{C}$ that due to their leading schools position the delivery of more advanced hardware is postponed until late starters had received their hardware.

This situation may slow down the development of computer use in such schools. Furthermore, different educational actors seem to be waiting for each other. Schools wait for teachers to start activities; teachers, however, wait for a policy at school level. Both schools and teachers are waiting for a policy at national level. The idea which is currently dominating at school is to avoid much change in the existing organization and curricula.

The innovation plans at national, as well as at school level, are merely directed at the fulfilling of some necessary conditions for computer use, such as provision of hardware, the training of a few teachers per school and providing a starter's package of software. A shortcoming of these plans is that little attention is paid to factors which are known to influence the implementation of an innovation.

It is important to realize that a real integration of computers in the curriculum comprises more than a simple innovation; it appears as a "bundle of innovations" with many components and persons involved [27]. Like most innovations, the integration of computer use in the classroom covers three dimensions of change (a) the use of new hardware and software materials; (b) the use of new activities, behaviours or practices in teaching and learning; and (c) changes in beliefs and understandings [17].

Fullan et al. [19], building on earlier publications, present a conceptual framework with ten research-based factors affecting the implementation of new technologies as an educational innovation in schools and classrooms. Each of these factors is analysed from both a "from above" 
and "up close" perspective. The first three factors are clustered as "characteristics of the innovation" itself: clarity and complexity of the innovation; consensus/conflict about the innovation; and quality/practicality of the innovation. The remaining seven factors belong to the "local conditions": central office direction, commitment and support; process for implementation and institutionalization; professional development and assistance; implementation monitoring and problem solving; principal's leadership; community support and environmental stability. A general conclusion in their study is that "using microcomputers and curriculum software in the classroom $(\ldots)$ represents a major and difficult change in practice for most teachers, and that effective utilization will depend on follow-through or ongoing assistance, clarification and innovation adaptation during the implementation, in addition to the availability of easy-to-use technologies, curriculum relevant software, and introductory training". Fullan et al. [19] add that "high uncertainty about the impact of the new technologies on learning outcomes and about the most effective methods of classroom use poses a major obstacle and challenge for implementation of the part of teachers and administrators". When analysing the results of our study of leading schools in The Netherlands in the context of the conclusion of Fullan et al. [19] and Plomp and van den Akker [27], we must conclude that at the level of national policy making (on which certain conditions and facilities are provided), as well as on the school level the state of the introduction of computers in education shows many discrepancies with the recommendations from the research literature. It would be worthwhile to investigate whether applying the strategies suggested in these studies will lead to better integration of computers in the curricula of our schools.

\section{REFERENCES}

1. Becker H. J., School uses of microcomputers, issue 1-6. The Johns Hopkins University, Center for the Social Organization of Schools, Baltimore, Md (1986).

2. Inspectorate (Dutch), Onderwijs en informatietechnologie: een beschrijving van de stand van zaken in het schooljaar 1985/1986 (Inspectierapport 7) (Education and Information technology: state of the art 1985/1986). Ministerie van Onderwijs en Wetenschappen, Inspectie voor Speciale Diensten, s'Hertogenbosch (1986).

3. van Deursen K., The introduction of information technology in the Dutch educational system. In CAL for Europe: Computer-Assisted Learning for Europe: Proceedings (Edited by Plomp Tj. et al.). North-Holland, Amsterdam (1987).

4. Cerych L., Computer education in six countries: policy problems and issues. Ministerie van Onderwijs en Wetenschappen, Den Haag (1982).

5. Plomp Tj. and van den Akker J. J. H., Curricular and implementation aspects of the introduction of information technology in education. In Eurit 86, Developments in Educational Software and Courseware (Edited by Moonen J. and Plomp Tj.). Pergamon Press, Oxford (1987).

6. Anderson J. S. A., Implementing information technology across the curriculum-what does it mean? In Eurit 86 , Developments in Educational Software and Courseware (Edited by Moonen J. and Plomp Tj.), Pergamon Press, Oxford (1987).

7. Collis B., Computers, Curriculum and Whole-Class Instruction: Issues and Ideas. Wadsworth, Belmont, Calif. (1988).

8. van der Geest Th. De computer in het schrijfonderwijs, perspectief voor een procesbenadering. (The computer in the teaching of writing: perspective for a process approach.) Universiteit Twente, Toegepaste Onderwijskunde Enschende, The Netherlands (1986).

9. Simon H. A., Designing organisations for an information rich world. In Computers, Communications and the Public Interest (Edited by Greenberger M.). Johns Hopkins Press, Baltimore, Md (1971).

10. Bergers A. H. and Achterberg A. M., The microcomputer in teaching school science and mathematics. Report of an International Workshop. Universiteit Twente en VALO, Enschede, The Netherlands (1986).

11. Moonen J. C. M. M., Toepassingen van computersystemen in het onderwijs. (Applications of computer systems in education.) Staatsuitgeverij, The Hague (1986).

12. Wiske M. S., Zodhiates Ph., Wilson B. et al., How Technology Affects Teaching. Educational Technology Center, Cambridge, Mass. (1988)

13. Becker H. J., Instructional uses of microcomputers, reports from the 1985 national survey, issue no. I. The Johns Hopkins University, Center for the Social Organization of Schools, Baltimore, Md (1986).

14. van der Linden W. J. Computerondersteund toetsen: technische ontwikkelingen en nieuwe toepassingsmogelijkheden. (Computer assisted testing: technical developments en new application possibilities.) In Onderwijs en Informatietechnologie (Edited by Heene J. and Plomp Tj.). Verslag van een SVO/CDO Symposium. SVO, The Hague (1985).

15. Zwarts M., Computerized testing service system: a description. In Develoments in Educational Software and Courseware (Edited by Moonen J. and Plomp Tj.), pp. 309-313. Pergamon Press, Oxford (1987).

16. Cory S., A 4-stage model of development for full implentation of computers for instruction in a school system. Comput. Teach. 11, 4 (1983).

17. Fullan M., The Meaning of Educational Change. Teachers College Press, Columbia University, N.Y. (1982).

18. Fullan M., Curriculum implementation. In The International Encyclopedia of Education (Edited by Husen $\mathrm{T}$. and Postlewaithe N.). Pergamon Press, Oxford (1985).

19. Fullan M., Miles M. M. and Anderson S. A., A conceptual plan for implementing the new information technology in Ontario schools. Ontario Ministry of Education, Toronto, Canada (1987).

20. Taba H., Curriculum Development: Theory and Practice. Harcourt, Brace \& World, New York (1962).

21. Gerlach V. S. and Ely D. P., Teaching and Media. A Systematic Approach. Prentice-Hall, Englewood Cliffs, N.J. (1980). 
22. Leithwood K. A., The dimensions of curriculum innovation. J. Curriculum Stud. 13, No. 1, 25-36 (1982).

23. Mudd S. and Wilson W., Achieving curriculum-integrated computing. Computers Educ. 11, 63-69 (1987).

24. Steerneman A. H. M., Veranderingen in het curriculum als gevolg van computergebruik: onderzoeksbeschrijvingen. (Changes in the curriculum as a consequence of computer use). Unpublished master's thesis, Department of Education, University of Twente, Enschede, The Netherlands (1988).

25. Yin R. K., Case Study Research: Design and Methods. Sage, Beverley Hills (1984).

26. Plomp $\mathrm{Tj}$. and Carleer $\mathrm{G}$., Towards a strategy for the introduciton of information and computer literacy courses (ICL). Computers Educ. 11, 1 (1987).

27. Plomp Tj. and van den Akker J. J. H., Computer integration in the curriculum: promises and problems. Paper presented at the Annual Meeting of the American Educational Research Association, New Orleans (April).

28. Plomp Tj., Steerneman A. H. S. and Pelgrum W. J., Curricular changes as a consequence of computer use. In Computers in Education (Edited by Lovis F. and Tagg E. D.), pp. 503-508. Elsevier Science, Amsterdam (1988). 